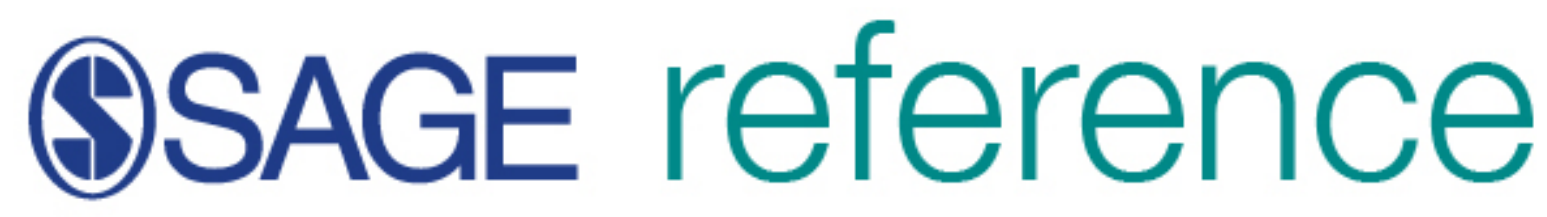

\title{
The SAGE International Encyclopedia of Mass Media and Society
}

\section{Ritual View}

Contributors: Rosalina P. Costa

Edited by: Debra L. Merskin

Book Title: The SAGE International Encyclopedia of Mass Media and Society

Chapter Title: "Ritual View"

Pub. Date: 2020

Access Date: December 13, 2019

Publishing Company: SAGE Publications, Inc.

City: Thousand Oaks,

Print ISBN: 9781483375533

Online ISBN: 9781483375519

DOI: http://dx.doi.org/10.4135/9781483375519.n572

Print pages: $1490-1491$

(C) 2020 SAGE Publications, Inc. All Rights Reserved.

This PDF has been generated from SAGE Knowledge. Please note that the pagination of the online version will vary from the pagination of the print book. 
A theoretical construct developed within the framework of communications theory, the ritual view concept, was primarily developed by James W. Carey (1934-2006) whose work distinguishes between the view of communication as ritual and the view of communication as the transmission of information. The ritual view emphasizes the power of communication in the construction and maintenance of a sense of community. This idea is consentaneous with the literature coming from the field of ritual studies.

As a focus of attention in diverse disciplines, rituals can be understood as events or occasions considered to be special and holding symbolic meanings shared among the participants who thereby feel interconnected. Nowadays, although some observers have advocated for the abandonment of ritual, others recognize its persistence as a powerful tool for constructing social reality and revealing its dynamics. Empirical studies conducted worldwide, especially in media ethnography, have contributed to confirm the continuing interest of using Carey's ritual view to understand the (in)visible dynamics of communities, not only on a local scale but increasingly in connecting globalization to lived local culture. This entry first compares the ritual view and the transmission view in Carey's conceptualization and then discusses how the ritual view relates to other research on communication and how it relates to the use of media, particularly online media.

The ritual view enables the representation, adaptation, and sharing of beliefs that allow for the development of a particular society, maintaining and reproducing it over time. In this sense, communication is used to bond people through their participation in or association with common experiences, norms, values, or beliefs. A ritual view of communication is central in the construction and maintenance of a sense of community. This idea is consentaneous with the original theoretical framework of ritual studies, often referring to the religious and the sacred sphere, whose ceremonies work in cementing common beliefs among participants.

Carey describes the ritual view as being in opposition to the transmission view. In the transmission view, the dissemination of information, rather than confirmation of existing beliefs, constitutes the primary feature. Sending, transmitting, and spreading information to others is how the transmission view operates. Communication in the transmission view is in large part for the purpose of control, according to Carey. From ancient Egypt to modern authoritarian regimes and contemporary global broadcasting, there are many examples of the use of communication as a method of control over large populations and geographical regions.

Besides the theoretical value of the distinction between the ritual and the transmission view, Carey acknowledges that such a dichotomy is far more artificial than real. In fact, the two views of communication coexist, thus offering a textured perspective of communication and enabling a broader understanding of the interaction in which humans engage.

Media theorists reflecting on rituals often rely on the historical and anthropological literature, as ritual studies are deeply intertwined with the origins of the social sciences. In this field, the first approaches mainly explored religion and religious behavior, partially due to the contributions of pioneering sociologist Émile Durkheim (1912) in The Elementary Forms of the Religious Life. Following the seminal work of Durkheim, major developments were undertaken by both sociologists and anthropologists in the 20th century. From functionalism to structuralism, and more recently symbolic interactionism, the ritual study moved beyond the sphere of the religious and into multilayered everyday practices and surrounding social interactions.

Elaborating from the rites of passage of Arnold Van Gennep, the liminal and liminoid rituals of Victor Turner, and the almost all-embracing rituals proposed by Erving Goffman, there is no single definition of ritual. Nonetheless, literature agrees that rituals differ from mere routines because they constitute a protected time and space. Rituals mark special events, days, or occasions with a different or symbolic meaning, which is shared among the participants who as a result feel interconnected with each other. This means that it is not the nature of the action or interaction that constructs a ritual but rather the meaning individuals ascribe to it.

In recent years, empirical studies come to confirm the power of Carey's ritual view and, moreover, the interest 
of using ritual as a tool to understand the contemporary usage of media. By way of example, the morning use of radio in a Danish family or the evening use of television in Brazil explored by Bent Steeg Larsen and Thomas Tufte illustrate how media use can be reinterpreted as rituals that express, maintain, and negotiate the existing social and cultural order.

Carey draws on the printed format newspaper as an example of mass media when discussing on the ritual view. Newspaper readership, indeed, can be envisaged as a mass community building as therein partial views of the social world are collected, portrayed, and later confirmed by individuals. The shift away from print newspapers to online news has brought with it multiple and fresh tools working for connectedness, namely, the ability to add online comments and the possibility of fast dissemination through social media such as Twitter, Facebook, LinkedIn, and Instagram. The multiple, sometimes simultaneous, actions of tweeting, following, capturing, sharing, adding, linking, or liking clearly show the ways in which social media enable the establishment, transformation, and maintenance of societal interaction between online, global communities.

While based upon diverse bonds that can be either direct or indirect and can involve business, academic, familial, and other relationships and multiple types of interests, including political or religious, the communities that develop online turn out to be quite real in terms of attachment, influence, pressure, and formation of public opinion. Global media have redefined community meaning, reshaping modes and contexts of reception, uses of media content, and meanings of media in the private and public lives of individuals and audiences. Carey's ritual view of communication fits this finding as showed by recent ethnography studies developed across many countries, emphasizing a vivid and creative connection of globalization to lived local culture.

See also Functionalist Theory; Globalization of Mass Media; Social Media; $\underline{\text { Structuralism; Transmission View }}$

Rosalina P. Costa

- rituals

http://dx.doi.org/10.4135/9781483375519.n572

10.4135/9781483375519.n572

\section{Further Readings}

Carey, J. W. (1989). Communication as culture: Essays on media and society. New York, NY: Routledge.

Durkheim, É. (1995). The elementary forms of religious life. Glencoe, IL: Free Press. (Original work published 1912)

Fiese, B. H. (2006). Family routines and rituals. New Haven, CT: Yale University Press.

Goffman, E. (1967). Interaction ritual: Essays on face-to-face behavior. New York, NY: Pantheon.

Larsen, B. S., \& Tufte, T. (2003). Rituals in the modern world: Applying the concept of ritual in media ethnography. In P. Murphy \& M. Kraidy (Eds.), Global media studies: Ethnographic perspectives. London, UK: Routledge.

Turner, V. (1995). The ritual process: Structure and antistructure. New York, NY: Aldine de Gruyter. (Original work published 1969)

Van Gennep, A. (1960). The rites of passage. Chicago, IL: University of Chicago Press. (Original work published 1929) 